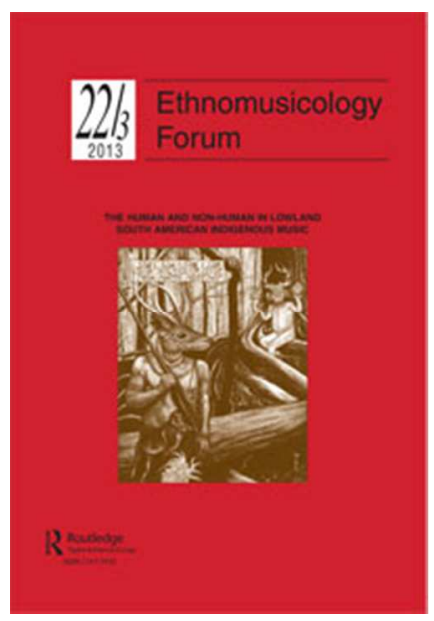

\title{
Musical Cosmopolitanism in Late-Colonial Hanoi
}

\begin{tabular}{|r|l|}
\hline Journal: & Ethnomusicology Forum \\
\hline Manuscript ID & REMF-2017-0051.R1 \\
\hline Manuscript Type: & Original Article \\
\hline Keywords: & \\
\hline & \\
\end{tabular}

SCHOLARONE ${ }^{m}$

Manuscripts 


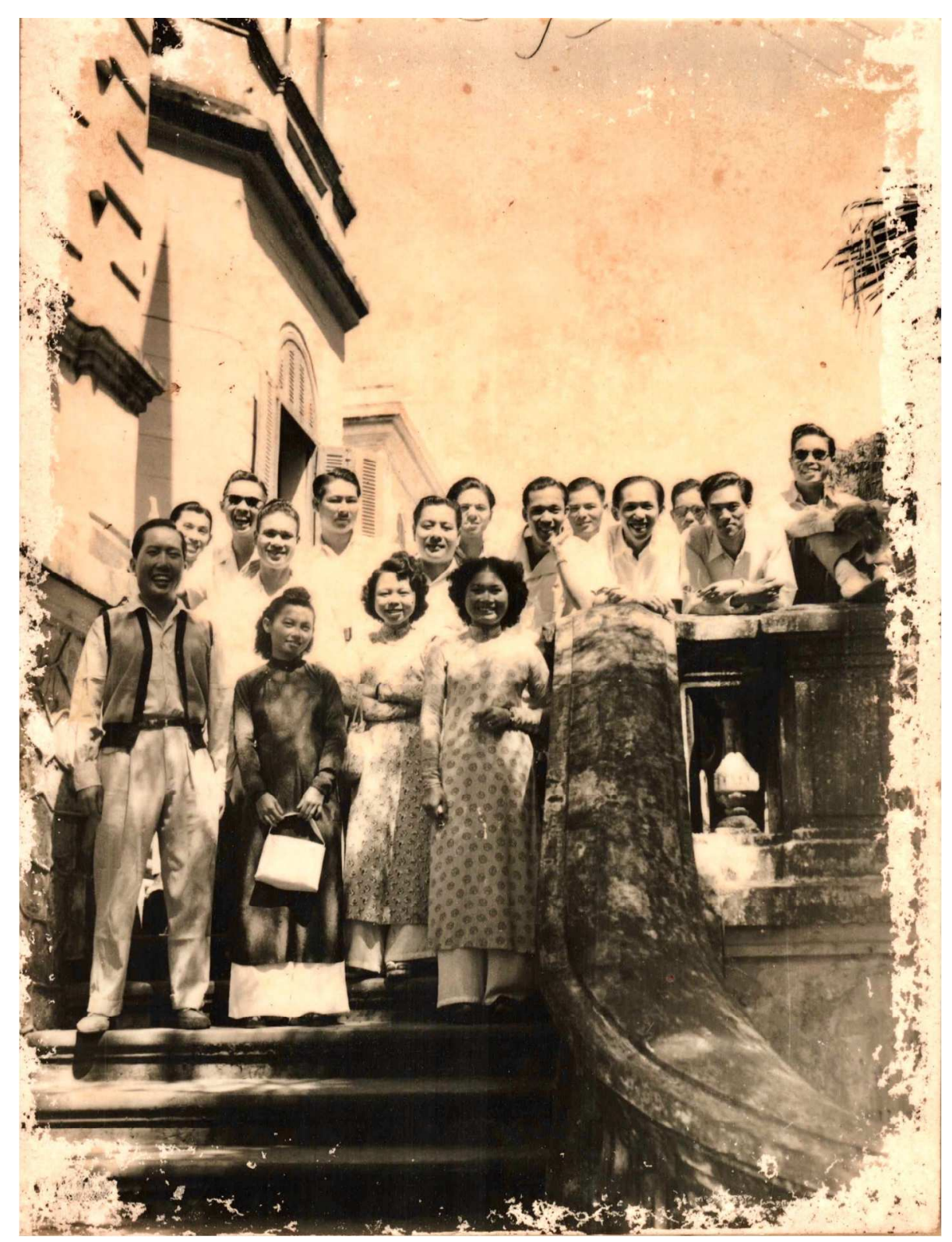

Figure 1 (see article text for complete caption) $179 \times 236 \mathrm{~mm}(300 \times 300$ DPI $)$ 


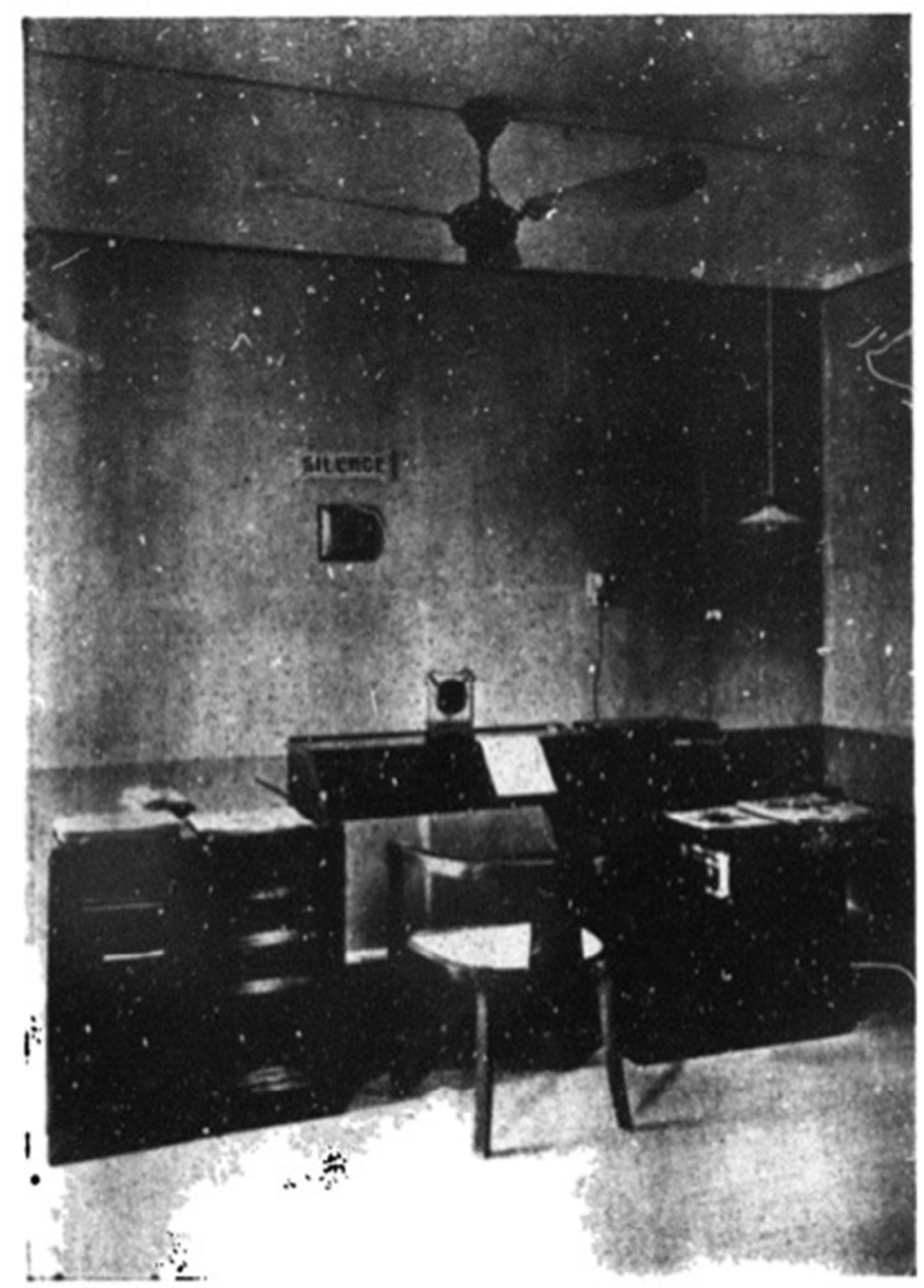

Lo studio.

Figure 2 (see article text for complete caption) $146 \times 214 \mathrm{~mm}(72 \times 72$ DPI $)$ 


\section{Musical Cosmopolitanism in Late-Colonial Hanoi}

This article investigates how radio was used to amplify the reach of vernacular forms of musical cosmopolitanism in late-colonial Hanoi. Between 1948 and the early 1950s, the musicians of Việt Nhạc - the first all-Vietnamese ensemble to appear regularly on Radio Hanoi-performed a unique blend of popular chansons in Vietnamese and local folk styles live on air to a radio audience across French Indochina. These creative artists sounded out the final stages of French imperialism in the region and its associated forms of Western Europeaninfluenced musical cosmopolitanism; they also nurtured an attentive radio listenership who gradually shifted their ears to Sino-Soviet-influenced musical cosmopolitanism following independence. Drawing on archival records, radio guides and interview data, this research excavates the story of the Việt Nhạc ensemble from the uncomfortable crevice between colonial and postcolonial history. In retelling this story, the writing interrogates the relationship between cultural and political change at the end of an empire.

Keywords: Vietnam; historical ethnomusicology; radio; colonialism; politics; cosmopolitanism 


\section{Acknowledgements}

I am grateful to Jason Gibbs for connecting me with Nguyễn Thiện Tơ, and to Tơ and my other research collaborators in Hanoi for being so generous with their time and energy. Thanks are also due to the two reviewers and Jann Pasler who provided exceptionally helpful feedback on earlier drafts of this essay, and to Tom Wagner, Tom Western and Abigail Wood for their work in compiling the issue. Any remaining faults are my own. Funding for this research was provided by the Arts and Humanities Research Council (UK). 


\section{Introduction}

On 17 February 2017, I visited the house of Nguyễn Thiện Tơ (b. 1921) on a busy street in central Hanoi. I was nine months into an eleven-month fieldtrip (June 2016 to April 2017) to research the musical history of Vietnamese radio. By that stage, I had developed a strong sense of the historical timeline from 1954 onwards, when Vietnam was divided into communist North (Democratic Republic of Vietnam; DRV) and capitalist South (Republic of Vietnam; RVN). Several Vietnamese sources repeated the same story: the first notable radio broadcast in Vietnam took place in 1945 when Hồ Chí Minh is thought to have read out the Declaration of Independence on air (Vũ, Lê and Trần 2015). Yet documents in the Vietnam National Archives I (VNA-I) contradict this official narrative. Tơ was one of several retired musicians I sought out for clarification. After I settled into the multipurpose living area of his small house, leaning against their upright piano and chatting with four generations of his musical family, To appeared in the doorway clutching a photograph (Figure 1). In his early 90s by this stage, he had poor hearing and was short on energy, yet the topic of conversation animated him. He pointed at the faces in the picture and explained that these people were the Việt Nhạc music ensemble, a group of musicians with whom he had the most fulfilling musical experiences of his life. What happened after Việt Minh revolutionaries took over in the 1950s? That was the end of this particular form of French-influenced cosmopolitan music in Hanoi. To joined the new station Voice of Vietnam Radio (Đài Tiếng nói Việt Nam) for a few years before moving to the orchestra of the Vietnam Feature Film Studio (Hãng phim truyện Việt Nam). Meanwhile, a different set of musicians and administrators took over the radio station to broadcast songs on political subjects influenced by musical trends current in other communist and socialist states. 
$<$ INSERT FIGURE 1 HERE $>$

Figure 1: Musicians of Radio Hanoi (Đài Phát thanh Hà Nội) pictured on the steps of the central recording studio in Quán Sứ Street, where the headquarters of the national radio broadcaster of Vietnam (Đài Tiếng nói Việt Nam) is currently located. The photograph is dated from 1949, although it may have been taken later than that. Back row: Canh Thân, Nghĩa, Nguyễn Hách Hiển, Bùi Ngọc Bảo, Nguyễn Văn Sợi, Nguyễn Đại, Vũ Thành, Nguyễn Thường, Nguyễn Thái Quy, Trần Văn Nhơn, Nguyễn Trí Nhượng, Nguyễn Thiện Tơ, Duc Thu; front row: Minh Đỗ, Minh Phương, Tâm Vấn. Photo: Nguyễn Trần Dũng.

This article recovers the story of the Việt Nhạc ensemble and situates their tale within the wider narrative arcs of French colonial and Vietnamese cultural history. Using the concept of 'vernacular cosmopolitanism' (Bhabha 1996; Werbner 2006) to explore localised manifestations of musical cosmopolitanism, the writing surveys the early history of sound reproduction in Indochina, activities of the first amateur radio clubs, broadcasts during the Japanese occupation, and the establishment of Radio Hanoi during the First Indochina War, before considering the musicians and musical outputs of the Việt Nhạc. The study argues that the demise of the Việt Nhạc was inevitable for artistic reasons because the forms of musical cosmopolitanism they espoused were incompatible with the dominant political ideologies of early postcolonial Vietnam.

\section{Vernacular musical cosmopolitanism in colonial and postcolonial Vietnam}

In his magnum opus, Trần Văn Khê argues that Vietnamese traditional musicians maintained a monopoly over radio broadcasts and recording studio activities up to 1939 . 
He was unable to adequately research Vietnamese popular music due to the lack of recordings and printed evidence (1962: 111). Although several amateur stations broadcast a plethora of musical styles to audiences in French Indochina prior to the 1940s, at Radio Hanoi the Việt Nhạc ensemble and its affiliated publications consolidated this diversity of styles. At the height of its influence, Radio Hanoi broadcast an array of Asian, European and North American recordings for up to eight hours per day. While broadcasters in colonial India used jazz to break the hegemony of European art music on air in the 1930s (Shope 2008), Vietnamese broadcasters mixed recordings of art music with jazz, French language chanson, light orchestras such as that of Nullo Romani and Vietnamese traditional music and theatrical styles. The musicians engaged their audiences outside of the recording studio in performances around Hanoi as well, including one widely publicised concert for patients at Bạch Mai hospital, which promoted the musicians as a collective ensemble for the people. Until its funding ceased, the Việt Nhạc was one of the most popular ensembles in French Indochina. The musicians assimilated international styles, infused them with Vietnamese musical inflections and broadcast them to an unprecedented number of listeners. This was a unique form of musical cosmopolitanism fuelled by sound recording and broadcasting technology and shaped by geopolitics.

Cosmopolitan musical styles have received a great deal of attention from ethnomusicologists. In his study of popular music in Zimbabwe, Turino identified 'cosmopolitan loops' that connected people and cultural trends beyond the local that are 'usually more heavily influenced by certain particularly powerful sites' (2000: 8). In late-colonial Hanoi, several distinct forms of vernacular cosmopolitanism existed which were influenced by the complex demographics and geopolitical landscape of the region. At that historical juncture in mainland Southeast Asia, two dominant forms of 
vernacular cosmopolitanism stood out. One leaned towards the powerful sites of Western European influence, and in Indochina was associated with French cultural imperialism and the premise of art for art's sake; the other was born of the Comintern, emphasised the motto of art for the masses, and was influenced by Sino-Soviet cultural trends, in particular, socialist realism. Ninh (2002) examines the emergence of the latter form of cosmopolitanism in Vietnam; the present research attempts to understand the gradual attenuation of the former ideology through a study of musicians who performed on the radio in late-colonial Hanoi.

In French Indochina (officially, 1887-1954), radio emerged as a focal point of social life for those who could afford it or who happened to live or work next to a radio owner. Forms of communal or semi-public listening, where owners placed radios on their windowsills in a public display of wealth (DeWald 2012), promoted the formation of diverse communities of listeners and amplified the audience numbers for broadcasts. Photographic evidence demonstrates that radio ownership was a mark of pride: families posed next to their radios, which occupied a central space in the homestead. The technology was quickly integrated into daily life, and people developed ways of listening and non-listening that presaged the techniques employed by citizens in contemporary Vietnam who are exposed to regular local authority broadcasts via wired loudspeaker. Radio was the first widespread form of broadcast media to transform the public sphere in Vietnam. ${ }^{1}$

The colonial authorities banned political content following several inflammatory broadcasts during World War II (Marr 1997: 81-82). Instead, public radio broadcasters were expected to focus on diverse, apolitical cultural themes and avoid fomenting

\footnotetext{
${ }^{1}$ See McHale (2004) for more information on the mass media, especially print, and its impact on the public sphere in twentieth-century Vietnam.
} 
discontent among listeners. On 31 August 1945, the Japanese transferred control of broadcasting facilities at Bạch Mai station in Hanoi to the Việt Minh. At the outbreak of the First Indochina War (1946-54) their station was overrun (Marr 1998: 11). The Việt Minh moved to the mountains southeast of Hanoi, where these insurrectionary voices resumed their broadcasts (Vũ, Lê and Trần 2015). In a battle for listeners, the French authorities intensified their support for radio during the late 1940s by temporarily increasing funding for Radio Hanoi, a station broadcasting from the city centre. These resources enabled station employees to establish a versatile radio music ensemble, the Việt Nhạc — the name translates roughly as 'Vietnamese music' or 'music of the Việt people'—which espoused a localised form of cosmopolitanism. Although the Việt Nhạc does not appear in any major collections on the history of Vietnamese radio (Phan et al. 1989; Nguyễn 2004; Vũ, Lê and Trần 2015), thousands of Vietnamese listeners regularly tuned into Radio Hanoi to hear its live performances before the station closed in the early $1950 \mathrm{~s}$.

\section{Sound reproduction in French Indochina}

At the dawn of the twentieth century, sound reproduction technology was popularised in the major regional hubs of French Indochina including Hanoi, Hải Phòng, Saigon, Vientiane and Phnom Penh. Radio was adopted for use by the military and transport workers but not initially as a means of entertainment (Lamarche 1949). In the 1910s, gramophone machines provided the first widespread means of access to recorded music and other forms of audio entertainment. Regular advertisements in Vietnamese newspapers illustrate how the major labels of the time--Victor, Odeon, Beka, Columbia 
and Pathé were prominent in French Indochina—-staked their claims to the market. ${ }^{2}$ One typical example advertises recordings from abroad alongside a selection of regional styles such as cái luoong (reformed theatre, particularly popular in southern Vietnam; see Gibbs 2000), hát tuồng, hát chèo (both theatrical forms popular in central and northern Vietnam; see Wettermark 2017 on tuồng and Meeker 2015 on chè), hát văn (trance recitation associated with chầu văn mediumship rituals; see Norton 2009), hát cô đầu (an early form of ca trù chamber music; see Norton 2014) and kể truyện (kể chuyện are recited stories; see Durand and Nguyen 1985). Although only a minority of locals could afford their own household gramophone machines or record collections, tea houses invested in these players and became the primary access points and places for debate about recorded music.

Several amateur radio stations were established in the 1920 s and 1930 s by a niche group of wealthy, predominantly European entrepreneurs to cater to the growing interest in broadcast sound. In 1928, Radio Sindex was the first officially licensed station in French Indochina. Three daily broadcasts were scheduled at $11.00 \mathrm{am}, 6.00 \mathrm{pm}$ and $8.30 \mathrm{pm}$ from the port city of Hải Phòng. Content included programmes on weather, news updates, exchange rates, trade and securities, and concerts of European, Vietnamese and Chinese music. Berg (2013: 288) counts nine registered stations operating in French Indochina up to 1945. This figure represents the number of different names of stations and not the actual number of broadcasters. In the colonial capital, for instance, Radio Hanoi, Radio-Club de l'Indochine du Nord and La Voix du Vietnam

\footnotetext{
${ }^{2}$ See Jason Gibb's active blog for an extensive compilation of advertisements for gramophone players, records, musical instruments, instrumental lessons and music performances in early twentieth-century French Indochina (http://taybui.blogspot.com, accessed 4 July 2017) and Gronow (1981) for a survey of record label catalogues and archives in the region.
} 
were effectively the same station. The catchy title, 'Voice of Vietnam' (Đài Tiếng nói Việt Nam; VOV), in its Vietnamese iteration was retrospectively and confusingly claimed by the Việt Minh as the official name of their station (see www.vov.vn); this strategic move facilitated the omission of Western European-backed stations from contemporary accounts of that period. Not all stations remained in the same location either: Radio Hirondelle, a French Army station initially based in Hanoi, moved south after the Geneva accords were signed in $1954 .^{3}$ During this pre-Indochinese War period, communities of amateur radio enthusiasts or radio hams sprouted up in all of the major urban centres of French Indochina.

\title{
The first amateur radio clubs (1928-39)
}

The popularisation of radio technology and the proliferation of stations unfolded in similar manner to the situation in pre-World War Two Malaya:

\begin{abstract}
Not only was the gramophone expensive, but also 78 RPM records were not durable in the humid and hot climate of the tropics. The radio was less expensive, was easier to maintain, and provided a greater variety of music. It was also a onetime investment, unlike the necessity of continuing to buy new discs. Thus radios and transistors began to replace the gramophone in public places. (Tan 1996/97:
\end{abstract} 34)

These stations did not entirely usurp the gramophone or other media technologies. Rather, radio was integrated into a multivalent print and broadcast media network that was used to inform and entertain the people. The immediacy of radio helped to position

\footnotetext{
${ }^{3} \mathrm{http}$ //www.radiotsf.fr/radio-sindex-la-premiere-radio-dindochine-est-nee-a-haiphong/, accessed 3 July 2017, and 'Création des diverses associations à Haiphong', VNA-I, Fonds de la Résidence supérieure au Tonkin, d79728-02. The former source lists the first broadcast from Radio Sindex as occurring in February 1928; the latter indicates that the station was not established until 21 July 1928.
} 
the technology as a central source of information. Whereas the gramophone era was defined by 'monopolistic control over both musicians and audiences' (Qureshi 1999: $64)$, the possibility of live broadcast via radio attenuated that control. However, the cost and technical issues due to equipment shortages, humidity, and a shortage of expertise limited accessibility. Respectable print media outlets redistributed the news via reports intercepted from abroad. Meanwhile, local radio hams established clubs with membership fees, strict regulations that had to be approved by the colonial authorities and periodicals that could be used to provide more financial stability to their enterprises by enhancing their audience and generating revenue through advertisements.

The more long lasting of the colonial broadcasters produced printed bulletins or journals alongside their audio broadcasts which were used as 'radio guides' (Pasler 2015) to educate listeners about complex transnational cultural trends with a distinct Western European emphasis. These guides publicised programme schedules, included information about off-air performances by radio musicians and affiliated performers, advertised radio equipment to facilitate public access and engagement with their stations and, perhaps most importantly for potential Vietnamese listeners, included directions for building homemade radios. On 15 August 1938, for instance, the Bulletin Officiel du Radio-Club de l'Indochine du Nord (henceforth, BORCIN) published four pages of directions on how to construct a radio at home using widely available and inexpensive equipment. Alongside official letters, orders, decrees and other documentation in the archives, these publications provide the most comprehensive data on the history of the stations because no recordings from any of the colonial broadcasters have survived to the present day.

During the first few years, the radio guides were published almost entirely in French, thus denying access to a non-French literate indigenous readership, the majority 
of the population, yet remaining accessible to French-educated Vietnamese. The most comprehensive of these guides, BORCIN, was published entirely in French, and each issue (published in 1935, 1937-9) contains more references to France and other European colonial powers than to mainland Southeast Asia. The first issue includes an opening address from the club's president and mayor of Hanoi, Henri Virgitti, in which he estimates that there are three to four hundred radio receivers in all of Indochina (Virgitti 1935: 4) - this number only represents the quantity of imported radios and does not include homemade devices. That first issue is an 88-page bulletin largely dedicated to the opening article, 'Le Tourisme par Radio' (Tourism by Radio), which details channels that can be received from around the world. Readers are told how and when to connect to France, Holland, England, French Morocco, Germany, Italy, the Vatican City, Spain, Belgium, Switzerland, the US, Australia, New Zealand, Java, Japan, Africa (stations listed by city only), South America (nine national stations listed) and Mexico - this globalising trend built on practices at other regional Indochinese stations in the 1930s. Thus, these guides and their affiliated stations presented 'a particular, historically contingent, cosmopolitan complex ... [which carried] connotations of elite status and sophistication' (Turino 2000: 8).

This perceived social standing can be further deduced from the advertisements in BORCIN; only luxury products (such as Moët \& Chandon champagne) are listed. The committee members of the club are named at the back of this issue along with the club regulations: Moreau Lebon, Guioneaud, Chaucot, Bouscaren, Saumont, de Condemoy. No Vietnamese names are included.

Club regulations created a further barrier to local engagement with this burgeoning broadcast media industry. Article 15 of the statutes of Radio-Club 
Tonkinois à Haiphong permitted one local representative out of eight committee members:

The Committee shall be composed of not more than six French members and two Asian members, including an Annamite member and a Chinese member, who shall be elected from among the active members and appointed annually for one year by the General Assembly. The members of the outgoing Committee are re-eligible. ${ }^{4}$

The Radio-Club de l'Indochine du Nord in Hanoi continued with this arrangement in the late 1930 s — the vice-president was Mr Long, a common first name for Vietnamese men. In contrast with Radio Hanoi in the late 1940s, which was almost entirely operated by the Vietnamese, and its flagship journal Việt-Nhac, which was published solely in Vietnamese, these clubs made inadequate tokenistic gestures towards the indigenous population.

Cross-pollination between French language periodicals and Vietnamese daily newspapers was usually unidirectional (European news to Vietnamese papers) and incomplete. In spite of the presence of amateur broadcasters from the late 1920s onwards, it was not until 1936 that an article appeared in the Vietnamese periodical Khoa Hoc (Science) with the declarative title, 'Hanoi has a Radio Station' (issue 127, 30 June 1936). This was their first public advertisement about the station for Vietnamese-language readers, although French-reading Vietnamese would have already been informed through French language guides and newspapers that targeted Vietnamese and other readers.

$<$ INSERT FIGURE 2 HERE $>$

\footnotetext{
4 'Création des diverses associations à Haiphong'. VNA-I, Fonds de la Résidence supérieure au Tonkin, d79728-02.
} 
Figure 2: Photo of the studio at the Radio-Club de l'Indochine du Nord taken in the mid-1930s and published in Ondes Indochinoises: Radio Hanoi (n.d.).

The colonial authorities' restrictions on indigenous engagement with radio contributed to stunting the growth of this medium, and few of the early stations lasted more than a couple of years. The first to close was Radio Sindex or, as it became known shortly after its launch, Radio l'Indochine à Hải Phòng. An exchange between $\mathrm{Mr}$ Bouchet in Hai Phong and the Resident Superier of Tonkin in Hanoi detailed the process of shutting down the station after only one year. Bouchet's letter from 11 December 1929 explains how the local court ordered the society to pay compensation to the director and return all the equipment:

The Society of Radio Indochine [in Hải Phòng] is in liquidation. This process was initiated by its director, Mr. Bellemin. The Haiphong court has ordered the Society to pay Mr. Bellemin $\$ 10,000$ in damages without delay, and a seizure of the equipment has been made. ${ }^{5}$

The equipment included a 100-watt substation as a power source and 100 vacuum tubes to broadcast the signal. Only 12 to 15 of the vacuum tubes were retrievable, with the rest missing or damaged. Adverse climatic conditions were a perpetual challenge for the Europeans. Their imported equipment was designed for more temperate, dry climates, and they had limited time and resources to overcome these issues. Electrification had not yet spread throughout the region either-in many parts of rural Vietnam this would not happen until the 1990s. This limited the potential to enhance audience numbers and build up sufficient independent revenue sources from advertisements. By the late 1930s, when the stations in Hanoi and Saigon were finally in more secure financial positions,

\footnotetext{
5 'Engagements pris par la Société Radio-Indochine à Hải Phòng envers le gouvernement provincial Yunnanais'. VNA-I, Archives Centrales de l'Indochine - Résidence Supériere au Tonkin, d40.988.
} 
war broke out in Europe. Funding and equipment donors ceased contributions, and the expatriate radio hams abandoned their sound recording and broadcasting equipment (Figure 2). In contrast with curtailment of expatriate-produced content for radio at the outbreak of World War II, a few eager locals who were marginalised from production prior to the war acquisitioned the technology and, in certain cases, redeployed it in support of the anti-colonial struggle.

\section{Instability and insurrection during the Japanese occupation (1940-5)}

The Japanese occupation of French Indochina (September 1940 to August 1945), the German occupation of Vichy France, and the Second Sino-Japanese War (1937-45) disrupted the trajectories of broadcast media in mainland Southeast Asia up to 1945. On 29 July 1941, the Vichy government signed a power-sharing agreement with the Japanese that permitted the French to maintain administrative control over public broadcasting during the occupation, albeit from their temporary federal capital in $\mathrm{Da}$ Lat. This agreement followed a decree on 20 November 1940 that banned the production and broadcast of any form of anti-imperial or anti-colonial broadcasts in public places (Đạo Luật ngày 20 November 1940 về việc nghe tin vô tuyến điện truyền thanh tại các nơi công cộng). An updated decree published in the newspaper Tràng An on 29 November 1941 specified that those found tuning into broadcasts by Mao's followers (người Hồng-mao) or any anti-French propaganda (propagande antinationale) would face extreme penalties. Cafes, tea houses, bars, hotels, theatres, clubs or any other public gathering place where these broadcasts were heard would be subject to closure for up to six months. Individuals found breaking these rules would have their radios confiscated, be subject to a fine of between 200 and 10,000 piastres and/or face a prison sentence of between six days and two years depending on the severity of their crime. While still struggling to contain anti-French propaganda, in June 
1943 Governor General Jean Decoux wrote to the employees of Radio Saigon to admonish them for straying from 'the facts' (les fait) about France's positive contribution to Indochina. ${ }^{6}$ These harsh penalties and repeated pleas evidence the fragility of the Franco-Japanese administration during the war.

Writing on the military potentials of radio technology, David Marr observes, ' $[\mathrm{t}]$ he radio receiver acquired an almost magical capacity to seize information out of the sky. Whoever controlled radio transmitters inside Indochina possessed considerable communicative power' (2013: 514). He estimates that by 1945 between two and three thousand registered radio receivers were in Vietnam (ibid: 516). Operable radios were used to pick up long-range broadcasts on the war in Europe. This information was often rebroadcast by Radio Hanoi or Radio Saigon and then printed in local newspapers. On 31 December 1942, for instance, Tràng An included a page of news dedicated to reports picked up by Radio Saigon. This included several updates from Saigon and Hanoi followed by news from France and its colonies (Tangier, Rabat, Dakar), England, the United States and Ankara. Reputable Hanoi-based newspaper outlets also owned radio receivers, which they used to redistribute news from abroad, and Catholic parishes often had one receiver to listen to news and reports from Europe.

These institutions needed suppliers to provide equipment and technical expertise. In Hanoi, several Vietnamese former assistants and clerks to the European radio hams were able to take over as storeowners. Radio Hanoi on Nhà Chung Street, which was run by Chu Thịnh and employed Vietnamese staffers who had been trained as assistants working for the Philips corporation (Nguyễn 1998: 25). In 1941, the

\footnotetext{
6 'Délivrance des documents relatifs aux activités financiers des Services de l'Indochine à la Radio-Saigon 1940, 1943, 1944'. VNA-I, Fonds de la Direction des Finances de l'Indochine, d16875.
} 
engineer Nguyễn Dực established his own eponymous radio store on Hàng Bài Street where he distributed and repaired receivers and sold records of music from around the world, which he had sourced on excursions to Bangkok and Singapore. These distributors' most reliable income source during the occupation was from the sale of Japanese records. They also sold public address systems for dance halls to play recordings and traders to amplify their advertisements - according to his son, on 2 September 1945, Nguyễn Dực used one of these systems to broadcast Hồ Chí Minh's voice when he read the Declaration of Independence in Bà Đinh square. ${ }^{7}$

This example illustrates how Vietnamese entrepreneurs exploited a commercial vacuum created during the Japanese occupation. Yet beyond a few wealthier families, and neighbours who could hear the broadcasts through open windows, still only a minority of the general public had access to radio receivers by the early 1940 s. The French administration required owners to register for a license, and frequently confiscated receivers at times of unrest (Marr 1998: 11). As the decade progressed, radio quickly shifted from the realm of the wealthy to a more accessible technology of the masses. In spite of strict regulations to the contrary, Japanese broadcasters managed to circulate messages in Vietnamese that encouraged pan-Asian unity (Marr 1997: 8182). Mass media were used to propagate the Japanese ideology of a Greater East Asia Co-Prosperity Sphere (Dai Tōa Kyōeiken), which encouraged East and Southeast Asians to unite together against the European colonisers. They also abstained from censoring Vietnamese broadcasters who challenged the French. Following a 9 March 1945 coup, the Japanese consolidated their power by confiscating receivers belonging to French citizens (Marr 2013: 514). Later that year, as the Japanese position in the Pacific War weakened, Vietnamese revolutionaries, who were aware of the potential of radio

\footnotetext{
${ }^{7}$ Interview with Nguyễn Lân Bình, 9 December 2016.
} 
technology to communicate across rugged terrain to the illiterate masses, sought to assert their own sonic power.

During the August Revolution (Cách mạng tháng Tám) against French rule in 1945, the Việt Minh commandeered French and Japanese broadcasting equipment at Đại La, just off Bạch Mai Street in southern Hanoi. Supporters of the movement who had been trained by colonial sound engineers used this equipment to produce political broadcasts that were interspersed with patriotic songs promoting the Communist Party and its leader, Hồ Chí Minh (see also Goscha 2012). Lê, a former musician with the group, reminisced about the sparse accompaniment of harmonica and banjo used when they performed 'Song of the Song Lo River' (Trường ca Sông Lô) by composer of the national anthem, Văn Cao, 'Lo Giang' (Lô Giang) by Lương Ngọc Trác, 'Thao River' (Du kích sông Thao) by incoming General Secretary of the Vietnam Musicians' Association, Đỗ Nhuận, and the iconic radio melody, 'Kill the Fascists' (Diệt phát xít) by Nguyễn Đình Thi (1995: 6-7). ${ }^{8}$ By late 1946, the French had regained control of most urban centres in Vietnam. Việt Minh radio - which would later become the official national broadcaster, the VOV—made its final broadcast from Hanoi on the evening of 19 December 1946 to declare the beginning of the war of independence. The radio technicians then moved their equipment to Chùa Trầm, an old temple in the hills southwest of Hanoi. There they began broadcasting as a pirate station in a battle of the airwaves with French-sponsored and licensed broadcasters in Hanoi (Vũ Hải, Lê and Trần 2015: 44-50).

\footnotetext{
${ }^{8}$ After the First Indochina War, an instrumental version of 'Kill the Fascists' was recorded for use as the signature musical jingle for the VOV.
} 


\section{Radio Hanoi during the First Indochina War (1946-54)}

In the city centre, Radio Hanoi (Đài Phát thanh Hà Nội) took over regular broadcasting responsibilities during the early stages of the First Indochina War (1946-54). Interim Vietnamese employees who had worked at the station during Japanese occupation took over more senior roles from 1946 onwards. No regular French or other European representatives were involved in production, as far as can be deduced from the archival records. However, just as in other contested colonial spaces (Scales 2010), colonial administrators and local sympathisers maintained a careful ear on broadcasts to avoid the dissemination of anti-colonial propaganda during those politically unstable times.

The Director General of Information and Press of the Provisional Central Government of Vietnam, Lê Văn Kim, was particularly active in his work on behalf of the station. Writing on 8 April 1949 to the publicist Pierre Argence in Paris, Lê responded to an advertisement he received the previous month from Archat-Dil Outremer about new equipment that could be purchased for the station:

\footnotetext{
For the realization of our programme, we will certainly have recourse to your organisation, whose experience and means have been confirmed. I am studying carefully the circular you have kindly sent me and will shortly submit to you full proposals. But today, I note in your leaflet a few articles of which I could place a firm order, after communication of your part of the conditions of purchase and delivery:
}

1. A magnetic tape recording apparatus, and the equipment therefor.

2. A double-plate disc recording apparatus and the material relating thereto.

3. The typewriter to write Vietnamese is of particular interest to us and we would like to know the cost (wholesale and retail).

This letter provides the only known evidence of an order for a sound recording device in Vietnam prior to 1954 . Unfortunately, the equipment and any recordings made with it have not been preserved, but the request itself demonstrates the desire of these 
administrators to build a station that could produce its own recordings for broadcast, maintain print and audio records of those activities and produce printed documents that could advertise the broadcasts to a Vietnamese readership.

The revived station appears initially to have been spearheaded by the influential musician and composer, Thẩm Oánh (1916-96). Thẩm Oánh grew up in Hanoi, where he studied art music and became known for his compositions of pre-war music (nhac tiền chiến; Lê 1970). Alongside his contribution to the radio, between 1948 and 1950 he served as editor of the journal Việt Nhạc (Nguyệt san Việt Nhạc), a vital 'organ for the promotion and propagation of music in Vietnam' (Gibbs 2017). The journal was structured similarly to the French-language BORCIN, which was in circulation when Thẩm Oánh was honing his skills as a musician and educator in Hanoi. Việt Nhạc articles of several pages in length introduce European art music composers and conductors and popular musicians from Europe and North America, provide information on forthcoming live concerts in Hanoi and music broadcasts by Radio Hanoi, and include promotional advertisements for local products including record and radio dealerships in Hanoi, Hai Phong and Saigon. ${ }^{9}$ The Việt Nhạc journal was exclusively produced by Vietnamese writers and written in Vietnamese for a native readership. Issues of Việt Nhac fulfilled a similar function to radio guides in the imperial centres of France, Great Britain, Germany and the United States by giving 'listeners a way of not only listening to music, but also thinking and talking about it' (Pasler 2015: 246). This illustrates the impact of the mission civilisatrice on Vietnamese

\footnotetext{
${ }^{9}$ Examples of the introductory articles include a two-page biographical sketch on Louis Armstrong (Việt Khúc 1949) and three pages on the Italian conductor, Pierino Gamba (Việt Khúc 1950).
} 
culture, even while the Việt Minh and other revolutionary factions were fighting for independence.

In reaction to anti-colonial content produced by the Việt Minh and the Japanese military band-inspired revolutionary themes that sporadically infiltrated the airwaves during World War II, all Radio Hanoi programmes had to be approved by Lê Văn Kim before they could be broadcast. Perhaps as a result of these restrictions, Thẩm Oánh stepped back from his role with the station sometime in 1949 after he had invited notable colleagues from Saigon to join the radio music ensemble. He was replaced by an administrator who was willing to devote more time to typing up playlists for the colonial administration than producing new content for listeners and readers. The following memo from Lê, dated 17 May 1949, details the new administrative structure:

The broadcasting department of the Voice of Vietnam (Đài Tiếng nói Việt Nam) is entrusted to Mr. DAM QUANG THIEN from Monday 16/5/49. The latter will report to the Director General of Information at the end of each week on the results of the new programmes for broadcast and propose any necessary modifications. Broadcasts in French continue to be the responsibility of Mr Rene LE VAN DUC. ${ }^{10}$

Đàm Quang Thiện was a doctor, author, film pioneer and member of the first Vietnamese parliament (Đại biểu Quốc hội Việt Nam khóa I; founded in 1946) representing the Việt Cách party. A Việt Minh military court sentenced him to death. This background suggests that he was senior to Thẩm Oánh, also came from a cultural background, was active in politics and had a reason to be strongly anti-

\footnotetext{
10 'Chương trình phát thanh âm nhạc của đài phát thanh tiếng nói Việt Nam, do ban Việt nhạc trình bày 1949 '.; VNA-I, Phông Sở Thông tin tuyên truyền Bắc Việt (hereafter PSTTBV), d219. Lê's reference to the station as the Voice of Vietnam using the Vietnamese term rather than Radio Hanoi challenges the standard historical narrative about the VOV.
} 
communist, hence his suitability for this role at the station. ${ }^{11}$

The prominence of Vietnamese language during Đàm's stewardship indicates that the French-funded Radio Hanoi was now directed primarily towards an indigenous Vietnamese audience. Partial documentation of the approval requests from this period are recorded in the VNA-1, and can be cross-referenced with the print advertisements for these broadcasts that were published in the specialised journal, Nguyệt san Việt Nhạc, and the more accessible daily newspaper, Tạp chí Tia Sáng, to describe the typical format of daily broadcasts. ${ }^{12}$ In 1949 , Radio Hanoi broadcast for over three hours in the morning entirely in Vietnamese and one hour in the evening in several languages. The evening broadcast was split into 20 minutes of French language news and 40 minutes of Vietnamese folksongs: chèo cổ (old-style chèo theatre), central Vietnamese folksongs ( $c$ a Huế) and northern folksongs feature prominently. Folk singer (ca sĩ dân gian) Mộng Hoàn and instrumentalist Nguyễn Trần Du were regularly advertised as soloists on these evening shows; these musicians performed Vietnamese folk music for Vietnamese audiences who may have had ties with the colonial establishment.

An editor's playlist from the first weekend of June 1951 provides further illustration of the place and relative importance of each programme to the broadcasters. By this stage, programming ran from 7:00am to $1: 30 \mathrm{pm}$ and from $5: 58 \mathrm{pm}$ to $9: 30 \mathrm{pm}$ each day. The morning broadcast ended and the evening broadcast started with two minutes of 'Music on a Green Day' (nhac ngày xanh), presumably a rendition of the song by Dương Thiệu Tước (1915-95), an important figure in the tân nhạc or nhạc cải

\footnotetext{
${ }^{11}$ http://dbqh.na.gov.vn/daibieu/19/0000000320/Đam-Quang-Thien.aspx (accessed 21 June 2018). I am grateful to Jason Gibbs for directing me to this information.

12 'Chương trình phát thanh của Đài phát thanh tiếng nói Việt Nam'. VNA-I, PSTTBV, d220.
} 
cách new music movement which emerged from Hanoi's tea house culture in the 1930s and 1940 s. ${ }^{13}$ Between each feature, which usually lasted between 10 and 30 minutes depending on the relevance of the programme, the editor played a musical interlude (labelled 'nhạc nôi'). News programmes were broadcast in Vietnamese, French, English and Chinese at fixed times during the day, and one update was broadcast on events in the United States. A second, longer form Vietnamese news programme was 'read slowly' at 8:01am to offer an opportunity for additional detail and elaboration. The frequency of these programmes and their place in the schedule illustrate their perceived importance for the editors.

Several music programmes were scheduled throughout the day on Friday 1 June 1951. One 26-minute programme dedicated to the music ensemble Việt Nhạc (ban đàn Viet-Nhac) at 1:01pm, one cái luơng reformed theatre programme, 21 minutes of records from abroad played at 7:40am and a further feature of pre-recorded art music from Europe in the evening. On 2 June, the Việt Nhạc programme was extended to 59 minutes — by far the longest programme on the schedule — and a programme dedicated to central Vietnamese folk songs (ca Huế) replaced the cải lưong feature. This rotation of programmes dedicated to Vietnamese traditional music, European art music and popular music from Europe and North America remained relatively consistent throughout 1951.

The styles of music played on gramophone records are listed on a separate sheet, which provides the only documentation available on the actual pieces of music played on the radio during this period. ${ }^{14}$ On Friday 1 June, three minutes was dedicated to each

\footnotetext{
${ }^{13}$ For further information on tân nhac see Henry (2005), Phạm (2006) and Gibbs (2008).

14 'Biên bản phát thanh của Đài phát thanh Hà Nội'. VNA-I, PSTTBV, d152 and 'Biên bản phát thanh của Đài phát thanh Hà Nội'. VNA-I, PSTTBV, d71.
} 
track to cover the full 21 minutes dedicated to the programme. This would have given the editor just enough time to change the record between each track, and no time would be spared for discussion or introduction. On Saturday 2 June, again three minutes was allocated to each track in the morning and the playlist and programme were shortened accordingly. Listeners could access broadcast timings via local newspapers, especially Tia Sáng, and develop more in-depth knowledge via the radio guide, Việt Nhạc. Those familiar with music at the tea houses of the early 1940s would recognise the musical styles, instruments and voices of singers such as Tino Rossi, Josephine Baker, Maurice Chevalier and Rina Ketty, which reinforced the Western European-influenced cosmopolitan culture of colonial Hanoi. ${ }^{15}$ The same records, and in certain cases perhaps even the same physical discs, were played on air via gramophone player.

Examples included contemporary hits and slightly older but still popular recordings in French such as 'Les Vieux Bateaux' ('The Old Boats', Edith Piaf, 1948) and 'Si Vous L'Avez Compris' ('If You Could Understand', Tino Rossi, 1938). Playlists from the period illustrate that popular chanson, arias from operettas in French and light

\footnotetext{
${ }^{15}$ Curiously, both Baker and Chevalier recorded versions of 'The Little Tonkin Girl' (Le Petite Tonkinoise), which included a chorus that could sound playful to Parisian audiences or offensive in an oppressed colonial setting:
}

It's me who is his little,

His Anana, his Anana, his Annamite

I am a vivid, I am charming

Like a little singing bird.

He calls me his lil' bourgeoise,

His Tonkiki, his Tonkiki, his Tonkin girl.

Others look at him with tender eyes,

But it's me he loves the best. 
instrumental tracks imported from Europe were the dominant pre-recorded styles broadcast to the listeners of Radio Hanoi.

In the evening, a shorter music programme started at 9:01pm and was dedicated to instrumental Western art music. On 2 June 1951, for instance, listeners were treated to a 1943 recording of Schumann's Violin Sonata No. 2 in D minor, Op 121, by Adolf Busch (violin) and Rudolf Serkin (piano) (Columbia Y3 34639) followed by Alfred Cortot playing Schumann's Etudes Symphoniques Op 13, recorded for Gramophone in 1929 (DB-1325). By December of the same year, when finances were under increasing pressure as the war intensified, the musical content for the evening programme changed to light popular styles similar to those played in the morning. The diligent recording and archiving of these playlists illustrates how the administration monitored broadcasts and maintained close control over radio as a means of propagating French soft power in the region.

Letters provide additional insights on the collection of records that were played on air. A letter from Mr Kiang Si-Ling, Consul General of China in Hanoi to Lê Văn Kim, dated 23 March 1949, demonstrates that beyond funding from the French administration, the station also relied on donations to build its collection of recordings:

In reply to your letter No. 288 / DGI of March 9, 1949, I have the honor to send you by separate package 8 Chinese (modern) music records.

I will not fail to send you other (classics) as soon as I have found them.

No Chinese recordings are listed in the approval requests. They may have been played as an introduction or interlude to the Chinese language news programmes, included in programmes for which the official requests are now lost, or simply donated as a gesture of goodwill. 
This diverse array of international musical styles_-French popular, European art, Vietnamese traditional and popular, and perhaps also Chinese and other regional traditional musics — was broadcast every week to thousands of people in Tonkin (northern Vietnam) and further afield. Recordings of popular chanson played in the morning and instrumental art music in the evening contributed a particular cosmopolitan flavour to musical life in the urban centres of French Indochina. These recordings must have whetted the public's appetite for Vietnamese language renditions of popular songs and built a fervent following for the Việt Nhạc ensemble.

\section{Forgotten musicians of the Việt Nhạc}

Few individual track lists were recorded for programmes of the Việt Nhạc ensemble or other features performed live on air by the artists of Radio Hanoi. The following information is gleaned from individual payslips of the station employees in 1949. These payslips include the names, roles and salaries of all performing artists at the station that year. When compiled into graphic format (Table 1), the information illustrates the size of the permanent music ensembles already broadcasting by the time Việt Minh radio (i.e., the VOV) announced their supposedly pioneering plan to establish a radio music troupe in 1949 (Phan et al. 1989). Altogether 13 instrumental musicians (nhạc sĩ), six singers ( $c a$ sĩ) and four voice actors (kịch sĩ) were paid regular salaries at Radio Hanoi. They were assigned to one of two roles: either directly to the station (Đài phát thanh) to perform theatrical plays and traditional folksongs (dân ca) or as part of the Việt Nhạc performance troupe. The former group could have represented each of the cultural regions of French Indochina - cải lưong for the south (Nam kỳ or Cochinchina), unless northern versions were broadcast, ca Huế for the centre (Trung kỳ or Annam) and hát chèo for the north (Bắc kỳ or Tonkin). However, the northern and central Vietnamese accents and dialects of the performers would have inflected the renditions and perhaps 
also appealed to their regional listeners.

\begin{tabular}{|l|l|l|}
\hline Name & Position & Salary \\
\hline Vũ Thành & Musician and conductor, Việt-Nhạc & 3,300 \\
\hline Trần Văn Nhơn & Musician, Đài Phát thanh & 2,500 \\
\hline Vĩnh Trần & Musician, Đài Phát thanh & 2,500 \\
\hline Anh Hồng & Voice Actor, Đài Phát thanh & 2,250 \\
\hline Bùi Thị Loan (Châu Loan) & Singer, Đài Phát thanh & 2,200 \\
\hline Đàm Thị Hoa (Mộng Hoàn) & Singer, Đài Phát thanh & 2,000 \\
\hline Nguyễn Thái Quy & Musician, Việt-Nhạc & 1,800 \\
\hline Bùi Ngọc Bảo (Ngọc Bảo) & Singer, Việt-Nhạc & 1,600 \\
\hline Đỗ Thị Nga (Minh Đỗ) & Singer, Việt-Nhạc & 1,600 \\
\hline Nguyễn Đại & Musician, Việt-Nhạc & 1,600 \\
\hline Nguyễn Hách Hiến & Musician, Việt-Nhạc & 1,600 \\
\hline Nguyễn Thiện Tơ & Musician, Việt-Nhạc & 1,600 \\
\hline Nguyễn Trần Dư & Musician, Việt-Nhạc & 1,600 \\
\hline Nguyễn Trí Nhượng & Musician, Việt-Nhạc & 1,600 \\
\hline Nguyễn Văn Sợi & Musician, Việt-Nhạc & 1,600 \\
\hline Nguyễn Thị Thọ (Bích Thọ) & Singer, Việt-Nhạc & 1,500 \\
\hline Nguyễn Thị Vĩnh (Ngọc Lan) & Voice Actor, Đài Phát thanh & 1,500 \\
\hline Nguyễn Thị Kim Lich & Voice Actor, Đài Phát thanh & 1,500 \\
\hline Linh Tâm & Voice Actor, Đài Phát thanh & 1,500 \\
\hline Trần Quan[g] Minh & Musician, Việt-Nhạc & 1,500 \\
\hline Đào Khanh & Musician, Việt-Nhạc & 1,300 \\
\hline Leisoui Ming & Promotions, Đài Phát thanh & 1,300 \\
\hline Ly Trung Dung & Translator, Đài Phát thanh & 1,200 \\
\hline Vũ Tuấn Đức & Musician, Đài Phát thanh & 1,000 \\
\hline Bùi Mè (Ba Mè) & Singer, Đài Phát thanh & 800 \\
\hline Nguyễn Thị Bảo Xuyến & Promotions, Đài Phát thanh & 800 \\
\hline Hoàng Văn Đức & Promotions, Đài Phát thanh & 500 \\
\hline Trịnh Dình Phi & Promotions, Đài Phát thanh & 500 \\
\hline & & \\
\hline & & \\
\hline & & \\
\hline
\end{tabular}

Table 1: Monthly payments to employees of Radio Hanoi in $1949 .{ }^{16}$

The salaries give an indication of the status of individuals and their respective

roles. Musicians were among the highest paid staff at the station, the promotions team

${ }^{16}$ Monthly salaries at the station were calculated according to the national fiscal budget for the year (chapter 16, article 4, section 1). Salaries were paid in Vietnamese đồng even though French Indochinese piastres were still in circulation. The purchasing power of this currency is difficult to assertain due to corruption, currency manipulations and dramatic fluctuations in the exchange rate during the war.

Although 'nhạc sĩ' typically translates as composer, at Radio Hanoi the composers doubled as instrumental musicians. Hence, they are labelled with the more generic term: musician.

Information collated from ‘Bổ nhiệm các nhan viên vào làm việc tại Đài phát thanh 1949', VNA-I, PSTTBV, d56-1. The spellings of these names are taken directly from the source and amended only where the names could be confirmed elsewhere. 
(quảng bá viên) and translators (người dịch) were among the lowest paid, and three of the four regular voice actors (kich sĩ) appear in the lower half of the table. Only Anh Hồng, a voice actor who was known for his singing ability and recitation of spoken theatre, was paid near the top of the scale. By tracing the biographies of the more notable performers, these payslips indicate the artistic styles that were performed live on air and the standing of particular musical and dramatic styles within the artistic landscape of Hanoi and its environs in the mid-twentieth century.

The ensemble was directed by Vũ Thành (1926-87), a conductor, composer and musician who honed his musical skills in the tea houses of Hanoi in the early 1940s. He learned flute from a French musician in Hanoi, occasionally sang, and was most renowned as a guitarist (Quỳnh 1988: 19-20). Phạm Duy, one of Vietnam's three most influential musicians of the twentieth century alongside Văn Cao and Trịnh Công Sơn, wrote in later life on his blog about the first tea houses of Hanoi ('Phòng Trà Đầu Tiên ở Hà Nội'). He recalled seeing Vũ Thành play flute and left-handed guitar in the Tuyết Sơn Tea House at the intersection of Hàng Bông and Thợ Nhuộm, two famous streets in the Old Quarter of the city:

[Vũ Thành] was the first composer of Vietnamese modern music (tân nhac) ... The songs ( $c a k h u ́ c$ ) of Vũ Thành were very elegant, like a breath of fresh air for the New Music movement (Tân Nhac).... Still with the same emotions of other musicians from that time, with references to love of the homeland, poetry, sorrow ... [and] the beauty of nature ... but the songs of Vũ Thành were not set to tango, rumba or slow foxtrot like those in the semi-classical style of the West, they sounded very luxurious and noble. ${ }^{17}$

This tribute praises a musician who has been ignored by scholars in Vietnam. In describing Vũ Thành's compositions as luxurious, noble and distinct from those heard

\footnotetext{
${ }^{17}$ http://www.phamduy2010.com/02sokhao/phongtra3.php (accessed 18 January 2017).
} 
in 'the West', Pham Duy highlights the originality of the compositions, which were largely written in later life. Vũ Thành was a key member of Radio Hanoi, as is evinced by his salary and job title. He wielded greater influence over the musical styles that people listened to in the city than any other Vietnamese person had done up to that point. Between 1948 and the early 1950s, he had the largest listenership, and he exposed them to a new world of Vietnamese traditional and modern music, regional styles of East and Southeast Asian music, and art and popular styles from Western Europe and North America.

The other outstanding figure composing in a contemporary modern style for Radio Hanoi was Trần Văn Nhơn (1912-73), whom Thẩm Oánh had invited up from Saigon to join the Việt Nhạc. Trần's most enduring composition, 'Hanoi 1949' (Hà Nội 49), illustrates his skilled appropriation and localisation of the popular chanson style for Vietnamese listeners. The melancholic lyrics romanticise pre-war Hanoi in the autumn, recall its century-old legacy and lament the ongoing turbulence in the city.

Bước men quanh hồ Hoàn Kiếm giũ̃a thu chiều úa,

Tôi nhớ tháng ngày sống nơi Thủ Đô hồi qua.

Hồ đẹp guơng nuớc liễu xua la đà bóng hồ,

Đời vui thái bình truớc lúc chiến tranh!

\author{
Strolling round Hoan Kiem lake on an autumn afternoon, \\ I remember the days I lived in the capital. \\ Long ago the lake was beautiful with glistening water \\ reflecting the willow trees above, \\ Oh, the peace of life before the war!
}

\begin{abstract}
Trần avoids excessive partisanship by emphasising the pre-1945 history of the city. The lyrics praise the spirit of the Vietnamese people — his audience — without making reference to other ethnic groups or nationalities, and descriptions of environmental degradation allude to wider issues in the colonial capital without explicitly apportioning blame, until he wishes for 'this time of sorrow' to end. This final phrase implies that life
\end{abstract}


would be easier if the insurrectionary forces of the Việt Minh and others ended their struggle.

Hà Nội yêu quý! Là chốn lịch sủ̉ ngàn năm,

Là trái tim của Việt Nam, là chính hồn Việt anh dũng!

Là nơ đẫm thắm, máu xurơng biết bao anh hùng,

Chính nơi muôn đời ghi dấu sử xanh thắm ghi chiến công!

Hà Nội yêu quý!

Cầu chúc cho ngày ấm êm,

Rày mau chấm dứt tháng ngày than khóc uu phiền!
Hanoi beloved! A place with a thousand years of history, The heart of Vietnam, the soul of the heroic Vietnamese! This place is drenched, blood and bones of many heros, The eternal place to mark a clear sign of victory!

Hanoi beloved!

We wish for a quiet day,

Hurry and end this time of sorrow!

The musical setting reflects the prevalence of Western European popular music in late-colonial Hanoi (see Gibbs 2008). 'Our songs following Western melodies’ (hát lời ta theo điệu Tây) was a popular compositional trend in the 1930s (Tô, Chí and Nguyễn [1977] 2003: 688-90). By the 1940s, composers in Hanoi moved on to writing original melodies inflected with Western European musical traits. Thẩm Oánh described the former trend as an attempt to find the 'Vietnamese Tino Rossi'. According to him, composers in China and Japan inspired the shift to original compositions (cited in Gibbs 2003/4: 73).

On a Saturday evening in January 1949, the popular singer Ngọc Bảo (19252006) performed 'Hanoi 49' on Radio Hanoi (Tia Sáng, 19 January 1949). ${ }^{18}$ In addition to his work at Radio Hanoi, Ngọc Bảo regularly performed in the tea houses of the city where musicians sang and played along with popular gramophone recordings imported

\footnotetext{
${ }^{18}$ Ngọc Bảo later became renowned as a singer of revolutionary songs. He is also credited as the first Vietnamese musician to be invited to the Pathé-Marconi Studios in Paris to record. In 1951, he recorded several songs with Guy Théven and his Orchestra. Five of these recordings are included on the recently released compilation, (Nhó Viêt Nam Xura) Nostalgique Vietnam: Chansons de Charme, Poèmes et Prières 1937-1954 (2014, Budapest Music Center, Catalogue no. 860245).
} 
from abroad. Quoted in his obituary, Ngọc Bảo recalled his exposure to these European and American recordings at the same club frequented by musicians he would later work with at Radio Hanoi:

I often skipped school to walk to the nearby Thiên Phúc Tea House on Hàng Gai street and listen to Tino [Rossi]'s voice. I spoke and sang along really well. Every evening at 9 or $10 \mathrm{pm}$, they turned on his music, and to this day I pause, enraptured, reciting from the beginning of every phrase, every word. (Quoted in Trần 2006)

Ngọc Bảo recorded 'Hanoi 49' in a crooning style with Trần Văn Lý’s band for Polyphon (57015). After a brief instrumental introduction, Ngọc Bảo enters in a playful, florid style with winding phrases sung using rapid, narrow vibrato and at a gentle volume suitable for intimate settings. The volume of the vocal line on the recording is uneven because the singer is also acting for his audience in the recording studio. One can almost hear the smile on his face as he moves from side to side, never consistently singing directly into the microphone, because he may have been more attuned to the tangible interaction with his live studio audience than with the inanimate recording device in front of him.

Trần's preference for Western European musical styles is evident in the score to 'Hanoi 49'. Written in a chanson style typical of Parisian café-concerts or European operettas of the 1920s and 1930s, the instrumental accompaniment comprises a small chamber ensemble of string-bass, wind instruments and piano. His arrangement for light café orchestra is remarkably similar to 'A Violin in the Night' (Un Violin dans la Nuit), recorded by Tino Rossi in 1935 for Columbia Records (CL5465). On Ngọc Bảo’s recording, a flute takes over the melody at the vocal break and is answered by a lowerpitched clarinet. String bass and piano maintain the harmonic rhythm while saxophones and a trumpet accompany the vocal line with an improvisatory countermelody. Ngọc Bảo's crooning vibrato is at a similar pace and width to that of Rossi. Violin and 
clarinet interludes and countermelodies fill the musical spaces at pauses between Rossi's phases, and harmonies shift from minor in the verse to major in the chorus, with a dramatic ritardando by the singer leading up to these transitions. In 'Hanoi 49', these harmonic shifts follow the lyrics as they describe contemporary (minor) and pre-war (major) Hanoi. Each phrase in the accompaniment of both songs ends with a heavy upbeat dominant chord followed by a light downbeat resolution to the tonic. In Ngọc Bảo's recording, this emphasis is most evident in the final two chords. His recording ends with a strong, sostenuto dominant followed by an inaudible resolution to the tonic, perhaps just after the maximum track length was exceeded.

These lyrical and musical features exemplify the music of the Việt Nhạc ensemble. The recording combines traits of the tân nhạc movement with Western European trends, all of which were made accessible by cultural currents that were facilitated by French colonial rule. The ensemble alternated between these trend-setting modern styles and local folksongs and folklore in Vietnamese as they sought to represent the majority ethnic group of Vietnam, their largest potential listenership, through contemporary forms of Vietnamese music. ${ }^{19}$ This diversity of styles became difficult to maintain when the flow of resources and recordings from Europe slowed.

As opposition to the recolonisation of Indochina grew in France and substantial material support for the Vietnamese communists began to arrive from Mao Zedong's communist China (1949 onwards), the People's Army of Vietnam were able to reverse the balance of power around the middle of 1950 (Brocheux and Hémery 2009: 361-70). War created an unbearable strain on the operational capacity of Radio Hanoi. European

\footnotetext{
${ }^{19}$ See Ó Briain (2018) for a consideration of musical representations of minority ethnic groups in the Vietnamese media.
} 
sources for creative material were less accessible, and French officials gradually reduced their financial backing and contribution of technical resources to the station.

The first indication that the musicians were unhappy appeared in the form of a letter of complaint from one of the highest paid singers, Mộng Hoàn, to the station's director on 30 March 1950. Even though they were experiencing one of their most active periods, Mộng Hoàn complained that she was not being repaid adequately for the money she had to give to her accompanying musicians. Vũ Thành followed up with another written plea for support on 21 December 1950, and then the senior musicians sent a co-authored letter of complaint on 18 January 1951. Finally, on 11 June 1951, Director General of Information Phạm Toàn wrote to the station's employees to renew their contracts. 15 employees were retained. Mộng Hoàn, author of the first letter of complaint, was not. Their contracts were only renewed for a period of six months from 30 June to 31 December $1951 .^{20}$ One month later, Director of Information in northern Vietnam Trần Quang Cấn wrote to the Head of the Ministry of Finance and the Financial Control Centre to explain that although they had promised to pay the employees' salaries, he did not have a sufficient budget to support the station for more than a few months. ${ }^{21}$ Playlist approval requests continued until the beginning of 1952 , which suggests that Radio Hanoi maintained a skeleton staff despite the cutbacks, but their activities appear to have ended shortly thereafter.

\footnotetext{
20 'Về việc trả lương cho các nhân viên của Đài Phát thanh Hà Nội. 1950-1951'. VNA-I, PSTTBV, d248.

21 'Về việc trả lương cho các nghệ sĩ công tác với Đài phát thanh Hà Nội của Sở Thông tin tuyên truyền Bắc Việt 1951'. VNA-I, PSTTBV, d247.
} 


\section{Political ideology and music}

Bothwell argues that pre-2011 revolution Syrian radio broadcasts excluded large segments of the population from their definitions of 'Syrian youths' by portraying 'a state-sanctioned map of Syria's future, which promised a place in that future only for certain types of listeners to the detriment of others' (2018: 105). Radio Hanoi empowered many of its listeners by positioning popular local styles such as ca Huế and cải lưong alongside international hits mostly produced in France and neighbouring European countries. However, segments of the population found closer political and cultural ties with the insurrectionary Việt Minh broadcasts concurrently available on receivers in northern Vietnam. When the Việt Minh returned to Hanoi to occupy the former premises of Radio Hanoi on Quán Sứ Street in the mid-1950s, they were able to establish a robust national media network by building on the creative foundations, sedimented technologies and attentive listenership of Radio Hanoi. The newly legitimised station pivoted from a cultural cosmopolitanism influenced by Western European trends to forms of programming that drew ideological and musical inspiration from the Soviet Union, China and other friendly socialist states. During the transition from colonial to postcolonial politics, when Vietnamese communism replaced French Indochinese capitalism, one dominant form of cosmopolitanism replaced another as a means of buttressing the political establishment.

Creative artists who were unwilling to produce art in the style of socialist realism either moved to the more liberal South or abstained from public performance. Musicians such as Thẩm Oánh, Vũ Thành and Trần Văn Nhơn moved to Saigon in the 1950s, where the tân nhạc movement thrived until 1975 (Henry 2005). Despite many key figures in the tân nhac movement hailing from central or northern Vietnam, experimental forms of cultural cosmopolitanism that fed the birth of the movement were suffocated in the North. A prominent study of the influence of European music on 
Vietnamese song from 1930 to 1950, which implicitly foregrounds musicians based in Hanoi, ignores all of the Radio Hanoi musicians in favour of naming composers who remained acceptable to communist cadres post-1954 (Vũ 1996). State institutions and a sizeable proportion of the population now memorialise the music and musicians that replaced the Việt Nhạc ensemble on public radio in the DRV. This memorialisation conjures a latent animosity and suspicion towards nonconformist cultural influences. By retelling the forgotten story of the Việt Nhạc ensemble at Radio Hanoi, this article partially diffuses that tension by explaining its origin: the emergence of new, rigidly socialist musical styles in the late 1950 s was made possible by the forced silencing of another vibrant performing arts scene, one which provided the musical and technological foundations for the establishment of an independent Vietnam.

References

Berg, Jerome S. 2013. The Early Shortwave Stations: A Broadcasting History Through 1945. Jefferson, NC: McFarland.

Bhabha, Homi. 1996. 'Unsatisfied: Notes on Vernacular Cosmopolitanism'. In Text and Nation: Cross-disciplinary Essays on Cultural and National Identities, edited by Laura Garcia-Morena and Peter C. Pfeifer, 191-207. London: Camden House.

Bothwell, Beau. 2018. 'State, Song, and Shabāb in Syria's Prewar Radioscape'. Asian Music 49(1): 80-119.

Brocheux, Pierre and Daniel Hémery. 2009. Indochina: An Ambiguous Colonization, 1858-1954. Translated from French by Ly Lan Dill-Klein with Eric Jennings, Nora Taylor and Noémi Tousignant. Berkeley: University of California Press.

DeWald, Erich. 2012. 'Taking to the Waves: Vietnamese society around the radio in the 1930s'. Modern Asian Studies 46(1): 143-65.

Durand, Maurice M. and Nguyen Tran Huan. 1985. An Introduction to Vietnamese Literature. New York: Columbia University Press.

Gibbs, Jason. 2000. 'Spoken Theater, La Scène Tonkinoise, and the First Modern Vietnamese Songs'. Asian Music 31(2): 1-33.

_ 2003/4. 'The West's Songs, Our Songs: The Introduction and Adaptation of Western. Popular Song in Vietnam before 1940'. Asian Music 35(1): 57-83. 
[2008. Rock Hà Nội và Rumba Củu Long: Câu Chuyện Âm Nhạc Việt Nam

[Hanoi Rock and Cuu Long Rumba: The Story of Vietnamese Music]. Hanoi: Nhà Xuất Bản Tri Thức.

_ _ 2017. 'Phụng sự cho nghệ thuật: Thẩm Oánh và ban đàn Myosotis (phần 1)'

[Serving the Arts: Thẩm Oánh and the group Myosotis (part 1)]. $B B C$

Vietnamese. http://www.bbc.com/vietnamese/vietnam-39620797.

Goscha, Christopher. 2012. 'Wiring Decolonization: Turning Technology against the Colonizer during the Indochina War, 1945-1954'. Comparative Studies in Society and History 54(4): 798-831.

Gronow, Pekka. 1981. 'The Record Industry Comes to the Orient'. Ethnomusicology 25(2): 251-84.

Henry, Eric. 2005. 'Tân Nhạc: Notes Toward a Social History of Vietnamese Music in the Twentieth Century'. Michigan Quarterly Review 44(1): 135-47.

Iriye, Akira. 1997. Cultural Internationalism and World Order. Baltimore: Johns Hopkins University Press.

Lamarche, J. 1949. 'Evolution de la Radio en Indochine' [Evolution of Radio in Indochina]. Bulletin de la Société des Études Indochinoises 24(4).

Lê Quý. 1995. 'Ban ca nhạc' Đầu tiên của Đài TNVN trong Kháng chiến’ [The First Music Ensemble of the Voice of Vietnam during the War]. Tạp chi Phát thanh 8 \& 9: 6-7.

Lê Thương. 1970. 'Nhạc Tiền Chiến - Lời thuật của Lê Thương’ [Pre-War Music - the Words of Lê Thương]. http://www.dongnhacxua.com/nhac-tien-chien-qua-loithuat-nhac-sy-le-thuong.

Marr, David G. 1997. Vietnam 1945: The Quest for Power. Berkeley: University of California Press.

—. 1998. 'Introduction'. In Mass Media in Vietnam, edited by David G. Marr, 126. Canberra: Department of Political and Social Change, Research School of Pacific and Asian Studies, Australian National University.

—. 2013. Vietnam: State, War, and Revolution (1945-1946). Berkeley: University of California Press.

McHale, Shawn F. 2004. Print and Power: Confucianism, Communism, and Buddhism in the Making of Modern Vietnam. Honolulu: University of Hawaii Press. 
Meeker, Lauren. 2015. 'Forgiving Thị Mầu, a Girl Who Dared to Defy: Performance Change and Chèo Theatre in Northern Vietnam'. Asian Theatre Journal 32(1): 136-58.

Norton, Barley. 2009. Songs for the Spirits: Music and Mediums in Modern Vietnam. Urbana and Chicago: University of Illinois Press.

- 2014. 'Music Revival, Ca Trù Ontologies, and Intangible Cultural Heritage in Vietnam'. In The Oxford Handbook of Music Revival, edited by Caroline Bithell and Juniper Hill, 158-79. New York: Oxford University Press.

Nguyễn Việt Hưng. 2004. Nưa thế kỷ phát thanh và truyền hình Hà Nội: 14-10-1954 đến 14-10-2004 [Half a Century of Hanoi Radio and Television: 14-10-1954 to 14-10-2004]. Hanoi: Nhà xuất bản Hà Nội.

Nguyễn Dực. 1998. 'Từ cái Máy hát đến Máy Thu thanh Đầu tiên ở Hà Nội’ [From the Gramophone to the First Audio Recorder in Hanoi]. Xua \& Nay 56: 23, 35.

Ninh, Kim N. B. 2002. A World Transformed: The Politics of Culture in Revolutionary Vietnam, 1945-1965. Ann Arbor, MI: University of Michigan Press.

Ó Briain, Lonán. 2018. Musical Minorities: The Sounds of Hmong Ethnicity in Northern Vietnam. New York: Oxford University Press.

Pasler, Jann. 2015. 'Writing for Radio Listeners in the 1930s: National Identity, Canonization, and Transnational Consensus from New York to Paris'. The Musical Quarterly 98(3): 212-62.

Phạm Duy. 2006. Tân nhạc Việt Nam thuỏ ban đầu [The Emergence of Tân nhạc in Vietnam]. Ho Chi Minh City: Nhà xuất bản Trẻ.

Phan Phúc et al. 1989. 40 Năm Đoàn ca nhạc Đài Tiếng nói Việt Nam [40 Years of the Voice of Vietnam Radio Music Ensembles]. Hà Nội: Nhà in BTTM.

Qureshi, Regula B. 1999. 'His Master's Voice? Exploring Qawwali and “Gramophone Culture" in South Asia'. Popular Music 18(1): 63-98.

Quỳnh Giao. 1988. 'Vũ Thành, Người nhạc sĩ Khí Khái và Ngạo Nghễ' [Vũ Thành, An Illustrious and Distinguished Musician]. Văn Học 26: 18-23.

Radio-Club de l'Indochine du Nord. N.d. Ondes Indochinoises: Radio Hanoi [Indochinese Waves: Radio Hanoi]. Hanoi: G. Taupin.

Scales, Rebecca P. 2010. 'Subversive Sound: Transnational Radio, Arabic Recordings, and the Dangers of Listening in French Colonial Algeria, 1934-1939'. Comparative Studies in Society and History 52(2): 384-417. 
Shope, Bradley. 2008. 'The Public Consumption of Western Music in Colonial India: From Imperialist Exclusivity to Global Receptivity'. South Asia: Journal of South Asian Studies 31(2): 271-89.

Tan Sooi Beng. 1996/97. 'The 78 RPM Record Industry in Malaya Prior to World War II'. Asian Music 28(1): 1-41.

Tô Vũ, Chí Vũ and Nguyễn Thuỵ Loang. (1977) 2003. ‘Âm nhạc phương Tây đã thâm nhập vào Việt Nam như thế nào?' [How has Western music infiltrated Vietnam?]. Reprinted in Hợp Tuyển Tài Liệu Nghiên Cưu Lý Luận Phê Bình Âm Nhạc Việt Nam Thế Kỷ XX, Tập VA, 673-690. Hanoi: Viện Âm Nhạc.

Trần Lê. 2006. 'Tài tử Ngọc Bảo: Người ra đi, lời ca ở lại!' [The performer Ngọc Bảo: He left, his voice stays!]. Nhịp cầu thế giới online. http://nhipcauthegioi.hu/Vanhoa/TAI-TU-NGOC-BAO-NGUOI-RA-DI-LOI-CA-O-LAI-2289.html.

Trần Văn Khê. 1962. La Musique Vietnamienne Traditionnelle [Vietnamese Traditional Music]. Paris: Presses Universitaires de France.

Việt Khúc. 1949. 'Louis Armstrong'. Việt Nhạc 26: 67.

—. 1950. 'Đời nhạc sĩ cổ kim: Pièrino Gamba, Nhac Trương Thân Dong' [Classical Musicians: Pierino Gamba, the Prodigal Conductor]. Việt Nhạc 35: 79.

Virgitti, Henri. 1935. 'Radio-appel' [Radio Calls]. BORCIN 1: 3-4.

Vũ Hải, Lê Đình Đạo and Trần Đức Nuôi, eds. 2015. 70 năm Đài Tiếng nói Việt Nam (1945 - 2015) [70 Years of the Voice of Vietnam]. Hanoi: Nhà xuất bản Chính trị Quốc gia.

Vũ Tự Lân. 1996. Nhũng ảnh hương của âm nhạc châu Âu trong ca khúc Việt Nam giai đoạn 1930-1950 [The influence of European music on Vietnamese song from 1930 to 1950]. Hà Nội: NXB Thế Giới.

Werbner, Pnina. 2006. 'Vernacular Cosmopolitanism'. Theory, Culture \& Society 2-3: 496-98.

Wettermark, Estbjörn. 2017. “"Như cá với nước - Like Fish and Water”: An Ethnographic Study of Instrumental Music, Timbre and Sentiment in Vietnamese Tuồng Opera'. PhD dissertation, Royal Holloway University of London. 